\begin{tabular}{|l|l|l||}
\hline \multicolumn{2}{|c|}{ PublisherInfo } \\
\hline \hline PublisherName & $:$ & BioMed Central \\
\hline \hline PublisherLocation & $:$ & London \\
\hline \hline PublisherImprintName & $:$ & BioMed Central \\
\hline \hline
\end{tabular}

\title{
Joining the dots
}

\begin{tabular}{|l|l|l||}
\hline \multicolumn{2}{|c|}{ ArticleInfo } \\
\hline \hline ArticleID & $:$ & 4805 \\
\hline \hline ArticleDOI & $:$ & $10.1186 /$ gb-spotlight-20030703-01 \\
\hline \hline ArticleCitationID & $:$ & spotlight-20030703-01 \\
\hline \hline ArticleSequenceNumber & $:$ & 157 \\
\hline \hline ArticleCategory & $:$ & Research news \\
\hline ArticleFirstPage & $:$ & 1 \\
\hline \hline ArticleLastPage & $:$ & 2 \\
\hline \hline & & RegistrationDate : 2003-7-3 \\
\hline ArticleHistory & $:$ & OnlineDate \\
\hline \hline ArticleCopyright & $:$ & BioMed Central Ltd2003 \\
\hline \hline ArticleGrants & $:$ & \\
\hline \hline ArticleContext & $:$ & 130594411 \\
\hline \hline
\end{tabular}




\section{Cathy Holding}

Email: cholding@hgmp.mrc.ac.uk

Therapeutic cloning could provide perfectly matched tissues and cells for use in the treatment of a wide range of diseases such as Parkinson's disease, and for the repair of damaged tissues, such as skin grafts to treat severe burns. In addition, constructing embryos from genetically-manipulated nuclei offers the potential for the production of therapeutic agents. However, the process of nuclear transfer to produce cell lines and clones is highly inefficient and the outcome is unpredictable. In the July 1 Current Biology, Fatima Santos and colleagues at the Babraham Institute demonstrate that embryos constructed by the transfer of nuclei from two different cell sources possess nuclei with different epigenotypes that result in different success rates in cloning, and that each of these parameters in the cloned embryos is different from those in the normally fertilized embryo (Current Biology 13:1116-1121, July 1, 2003).

Santos et al. visualized the methylation status of individual nuclei in single embryos by using highly sensitive fluorescent antibodies specific to both the methylation and acetylation status of the histone $\mathrm{H} 3$ lysine 9, previously shown to be closely linked to the overall methylation and expression status of genes. They compared the frequency of normal and abnormal epigenetic marks between control and cloned embryos, and found a ten-fold difference in the staining between the two groups. In addition they showed that the epigenetic asymmetry resulting from reprogramming in lineage-delineated control blastocysts failed to occur in the cloned embryos. By examining the epigenotypes of cells derived from relatively more-differentiated fibroblasts and those from less-differentiated granulosa cells, they observed that significantly more of the latter cells had normal methylation patterns, with nearly twice as many achieving blastocysts.

"Our results strongly suggest that, for cloned embryos, epigenetic variations in donor cells along with partial reprogramming results in heterogeneity of epigenetic marking, which is responsible for their developmental potential," conclude the authors.

\section{References}

1. Therapeutic cloning: concepts and practicalities

2. Generation of mice from wild-type and targeted ES cells by nuclear cloning

3. Current Biology, [http://www.current-biology.com/]

4. The Babraham Institute, [http://www.babraham.ac.uk] 